\title{
Sociabilité of Workers and the Working Class in Comparative Perspective, 1850-1950
}

\author{
Ellen Ross \\ Ramapo College
}

\begin{abstract}
An international colloquium, "Sociabilité of Workers and the Working Class in Historical Perspective," which I attended along with eight other Americans, took place in Paris on November 28 and 29, 1985. About forty people, mostly but not exclusively historians, from eight countries attended this event. The conference was organized by representatives of $I L W C H$ and Le Mouvement social, and was sponsored and funded by the French Ministry of Education, CNRS, and the Maison des sciences de l'homme, the last of which handled the conference details with grace and efficiency. Patrick Fridenson, representing Mouvement social, and Helmut Gruber of $I L W C H$, served as an overworked two-man program committee. Meetings of a similar format have been taking place every few years for the past decade, though involving many fewer Americans than this one did; one of the purposes of this meeting was to extend the research and friendship networks of social historians to a broader group of younger researchers. Around a third of the participants were women, apparently more than at past colloquia.
\end{abstract}

The conference format was odd, but it worked. Seven papers in English or French had been distributed beforehand, and two or three of these formed the basis of discussion at each of three half-day sessions. The final session was reserved for "Synthesis," and was formidably titled "Sociabilité in the Workers' Private Sphere within the Context of the Dominant Bourgeois Culture." After short formal introductions, sessions were devoted entirely to discussion, with periodic translations into French or English by three bilingual colleagues. The very diverse participants did seem to coalesce as a group by the meeting's end, and had certainly worked hard for the duration; the first day's session ran from 9:30 a.m. until 7 p.m. On the first day, many "interventions" were often very long and interrupted the general flow of discussion. A chorus of complaints to the organizers resulted in tighter chairing and better discussion on the next day.

I was enthralled by the proceedings, functioning cheerfully on jet-lag and two hours of sleep nightly. What was so spell-binding is hard to pin down, however. Surely some of the excitement came from meeting long-admired "names", in person: Michelle Perrot (University of Paris VII), Jacques Ran-

\section{International Labor and Working Class History}

No. 29 , Spring 1986 , pp. 102-108

(C) 1986 by the Board of Trustees of the University of Illinois 
cière (University of Paris VIII), Lutz Niethammer (Essen University). Also, the conference did present itself as a labor history forum which was seriously interested in digesting some of the conclusions of women's history, an exciting prospect for me. Finally, we were probably all stretched by new conceptual styles and bodies of fact, from the efforts of French or Austrian socialist municipalities to channel the exuberant street life of workers, to the dangers of celebrating the Fourth of July in the post-bellum American south, to warnings that material conditions were in no way adequate in explaining the development of workers' consciousness.

$I L W C H$ readers may well wonder what a conference dealing with " $L a$ Sociabilité ouvrière" could possibly be about, and this was a question that many participants themselves asked throughout. The fact that the three main sessions were titled in terms that implied classification rather than analysis ("Form of Sociabilité"; "Time of Sociabilité"; "Place of Sociabilité") did not shed much light on the question. Maurice Agulhon had used the concept fruitfully, it was pointed out, in La République au Village, and explained it in his English article "Working Class and Sociability in France before 1848," in Crossick et al. The Power of the Past. Vague as it is, the concept of "sociabilité" represented a sensible compromise between the languages and interests of historians from different places along the Atlantic and different stances in relation to labor history. The seven common conference papers dealt with all kinds of workers' relationships and activities but only very incidentally touched on formal organizations like unions or political parties.

I have tried to provide a synopsis of the main directions of the two-day discussion, but there are large gaps where my comprehension, recording skills, or interest, flagged. Nearly everyone present participated very actively, though here I have not named every voice. I regret too that I have unavoidably translated the many different intellectual and political tones I heard in Paris into my own common-sense Anglo-American empiricism.

The first session, "Form of Sociabilité: Family; Age Groups, Friends and Colleagues; Other Networks," was based on papers by Christine Stansell (Princeton) on heterosexual sociability in early nineteenth-century New York, and by Maurizio Gribaudi (Turin University) on working peoples' movements into, out of, and within Turin during the first half of the twentieth century. Stansell's work spoke of hostility and violence between the sexes-regulated by neighborhood "rules" - as well as of moments and places of pleasure and friendship between (young) men and women on the Bowery, which in the 1830 s had become a zone where courtship could proceed with less of the rough and overtly misogynist male behavior than had characterized earlier forms of public heterosexual sociability. Gribaudi studied the enormous physical mobility of the Turin workers, from neighborhood to neighborhood, and from country villages to jobs in the city and then back again, and finally, from un- 
skilled to skilled work or even into white-collar posts. This picture, for him, exploded the notion of "working class" as any sort of static category based on a person's relationship to a work role.

A number of people questioned the value of Stansell's court records for analyzing domestic violence, arguing that they registered the behavior of "deviants" or were bound to overemphasize conflict. Michelle Perrot responded that court records were only now being exploited in France as a rich source of information on popular social life. Ewa Morawska (University of Pennsylvania) wondered whether there were differences in the courting or family behavior of New Yorkers according to their country of national origin: Irish, German, or Yankee. Alain Cottereau (Ecole des hautes études en sciences sociales, Paris) wondered what had happened in New York, to the popular festivals which continued to thrive in contemporaneous Europe. Michelle Perrot was struck by the "rôle du cri" which, in the case of a wife-beating in nineteenth-century New York, brought a "private" event to the attention of the neighborhood and thus transformed it quickly into an occasion for public intervention.

In response to Gribaudi's main argument, Paul Thompson (University of Essex) said that the term "working class" ought to be retained to describe those holding factory jobs, regardless of the status of their children or of their own migration history. Gerhard Haupt (Bremen University) asserted that the concept of working class identity is itself dangerously teleological, since it supposes that workers have only one identity; in fact they have many kinds of self definition. Stephen Yeo (University of Sussex) suggested that the Jungian concept of the personna was an excellent way of conceptualizing the many guises in which a working-class person can present himself or herself: by gender, ethnicity, class, "respectability," etc. (Throughout the conference the concept of "respectability" was set up hopefully by some, only to be contemptuously batted down by others, and thus received no sustained discussion.) Gribaudi's paper also directed attention to the effect of Fascism on working-class neighborhood culture, for, in Turin the generation who were adults in the 1930s had far less commitment to quartier social networks than to friendships distributed throughout the town, and the predominantly socialist vocabulary permeating neighborhood contacts had begun to dissolve. Lutz Niethammer, describing his experience with an oral history project focused on the Ruhr in the interwar period, felt that Gribaudi's reasoning implied that Turin's social structure had simply "delivered" people to the Fascists, without their exercising any real agency.

In relation to both papers there was considerable discussion of the role of the church and the sort of sociability it fostered, a question first raised by Barbara Fields (University of Michigan). Participants speculated that churches might have attempted to teach more wifely submission, or male forbearance from violence, but would, in any case, be intervening in the relationships of 
couples. Roy Rosenzweig (George Mason University) noted that the Germans in New York at mid-century did have an elaborate calendar of church picnics and festivals. Rolande Trempé (University of Toulouse II) affirmed the activity of the French Catholic church, on the parish level, in providing services, and sponsoring clubs for men and women of all ages, and noted its importance in the history of the family in France. Throughout the nineteenth century, the French bourgeoisie was anti-clerical, she continued; some bourgeois political clubs actively recruited artisans and other workers and thus consciously attempted to spread this secularism to workers.

The session titled "Time of Sociabilite: a Day, a Year, a Life," dealt with papers by Gérard Noiriel (Ecole Normale Supérieure, Paris) on the Lorraine steel industry from 1900 to 1930, and Roy Rosenzweig's study of Fourth of July celebrations in Worcester, Massachusetts (1870-1920). Noiriel's was a case study in employer domination of nearly every aspect of working-class life in an industry with very large firms, low wages, and a workforce that included a large, shifting population of immigrant single men and a smaller group of married workers living in company housing closely regulated by the patronat. Noiriel clearly wanted this paper to demonstrate how little space, time, or freedom there was for any autonomous working-class social life. Rosenzweig's paper, however, discussed working-class celebrations of a day which was officially "theirs," and examined the working-class Irish, Swedish, and FrenchCanadian festivities as well as the more sedate and family-oriented observances of the town notables. He traced both the efforts of the latter, toward the end of the century, to "tame" the exuberant drinking and fireworks of many of the ethnic festivities, and the penetration of commercial amusements - theaters and amusement parks - in a formerly self-organized holiday.

The juxtaposition of these two papers was the basis of a discussion one of whose major themes, not surprisingly, was the polarity of working-class oppression versus autonomy. Participants were reluctant to believe that the Lorraine patronat had such total power over the lives of their workers. Noiriel responded with evidence that local "festivals" were all concocted or reorganized by the bosses; that they fought to prevent the growth of a rival ruling class of teachers and other functionaries which might have helped workers gain some leverage against them; and he noted the ethnic divisions in which Poles generally occupied unskilled positions, while the French workers advanced to higher places in the occupational hierarchy. Goffman's "total institution" struck Noiriel as the best model for analyzing working-class life in most of the Lorraine steel towns.

Rosenzweig's paper generated an analysis by the group of the history of working-class leisure which critiqued Rosenzweig's implied contrast between "spontaneous" and "commercialized" leisure forms. Popular leisure, even in its "traditional" seventeenth- and eighteenth-century forms, had always involved commerce, Geoff Crossick pointed out; publicans, bookmakers, mar- 
ket-stall holders-all sought profit from the amusements of the poor. Stephen Yeo observed that even in such commercial forms of leisure as music-halls and football games there is an enormous amount of audience activity and participation. Lutz Niethammer asked a new question about leisure, which no one could answer: What is the alternative to mass culture for working-class males? If they could choose, what would they in fact want to be doing in their free time? He was fairly sure that it was not what was suggested in a post World War II German government poster campaign which showed a little boy saying: "Saturday Daddy belongs to me!" A number of the participants noted that for women, the history of leisure was very different from the one we had been sketching out for men. Industrial time meant different and often more difficult schedules of domestic work; the improvement of working-class standards of living in late nineteenth-century Britain may well have amounted to a "speed-up" for workers' wives who needed to care for more clothing, prepare more elaborate meals, etc. In both Rosenzweig's and Noiriel's papers, ethnic differences among workers were a substantial subtheme, and the importance of such divisions in impeding common action and the growth of a common consciousness was a theme in this session's discussion.

A study by Alf Lüdtke (Max-Planck Institut, Göttingen), which was distributed at the conference itself, was discussed more briefly. It dealt with shopfloor culture in German factories between 1870 and 1940. Instead of studying the social origins, voting behavior, etc. of the workers, Lüdtke looked closely at the texture of daily life in the factory itself: forms of address between the men (Sie and $d u$ ), the size of the group of which the men considered themselves members, the "rights" even those in subordinate positions considered themselves entitled to from other workers and from management. He used the term Eigensinn to characterize the workers' stance with regard to their bosses, a term which no one could translate into English with any success, but which connotes a child's half-hearted compliance with an adult's command.

The subject of the next morning's discussion was the culture of "the streets": Reinhard Sieder's (University of Vienna) study of working-class children in Vienna from 1900 to 1934, and William Reddy's (Duke University) paper on street life and popular morality as portrayed in mid-nineteenthcentury Lille dialect literature. Sieder's paper, based on a large group of oral histories, looked both at official attitudes toward the Gassenkind and at the games and rules boys devised for themselves in the relatively open spaces around the city, as well as in the streets of the worker districts. The experience of "possessing" these streets, Sieder speculates, helped to make them effective anti-Fascist street fighters during the worker rising of February 1934. Reddy's demonstration of working-class identification with a geographical locality, based on a reading of two long works by a local dialect poet whose success led to a clerical job and residence in a "better" part of the town, generated several 
lines of inquiry. Among the most interesting was the place of small shopkeepers, peddlers, cabaret-keepers and the like in working-class neighborhood life. Ewa Morawska's data from Johnstown, Pennsylvania in the early twentieth century showed a huge turnover among small merchants and constant shifting of men back and forth between shop and factory. Jacques Rancière suggested that small merchants are central in working-class life because, like poets and political activists, they "talk" with people as they engage in cash exchanges in their quartiers. This talk, by those at the edges of the working class, does help define the working-class community for itself.

Sieder came in for a fair amount of criticism for his relatively uncritical use of his oral sources, as did Reddy, for his use of literary sources, but a number of participants pointed out that all sources, oral or written, are "literary," and have their distinct conventions which the historian has to decipher. Karin Hausen (Technische Universität, Berlin) thought Sieder should have made an effort to find relationships between homes and streets, for, as the power of le cri in New York had suggested, in working-class areas there has been little separation between public and private spaces. Hausen and Marianne Debouzy (University of Paris VIII) both noted that parents, mothers especially, did exercise considerable supervision over children even when they were away from home; children may have felt "free,' 'but local matrons were constantly checking up on them. Hausen also observed that Sieder was in fact describing the street life of boys, because girls, so often responsible for the care of small children, moved within a far smaller radius of the home than did their brothers.

The final, synthetic session, introduced by Bryan Palmer (Queen's University, Ontario), began with some criticisms of preceeding sessions: they had concentrated on male sociability, ignoring what were likely very different patterns for women; they had similarly ignored workers "at the margins," especially black workers for whom traditional forms of organization and protest were out of the question; they had not discussed the often hostile and always complex relationships between the sociabilite of the streets and cafes and the "formal" working-class movements and organizations. All of these were quite fair assessments. Particularly disappointing to me was the group's failure to make a major commitment to integrating the mostly female-centered sociability of the home and neighborhood into the male worlds which did remain the focus of our discussions. Another conference paper dealing perhaps with neighborhood culture might have encouraged that project.

"Ambiguity,"' denoting the double elements of accommodation and resistance in the history of the working class in the West, was a term which was repeatedly offered in earlier sessions and was now further refined as less a question of actions themselves than of the way they are interpreted by contemporaries; in any setting there is a pluralite of meanings and actions. "Polyvalence" was the term suggested by Luisa Passerini (University of Turin), as there is no one tra- 
jectory leading toward "liberation," and hence no stable vantage point from which to judge historical events. Lutz Niethammer was struck by the contrast between the focus of the 1985 conference and that of similar meetings in the last two decades: neither the labor movement nor the state had been discussed this time, and the question of why socialism had not been able to establish itself in Europe seemed to have vanished. Several speakers then agreed that interest in the "spontaneous" elements of working-class social life was probably related to disappointment with the older project of labor history. Though it was time to disband at this point, we decided to extend the discussion, hoping to reach a less grim resolution, and despite terminal exhaustion, many rose to the occasion. Links between "sociabilité" and formal politics did exist. Annie Fourcaut (Ecole Normale Supérieure de Fontenay-aux-Roses) observed that Agulhon's La République au Village demonstrated a strong relationship between patterns of village sociability and the acceptance of the institutions of the Second Republic. We had indeed not given up the search for ways to promote socialism, but need new categories to analyze the failures of the past and the possibilities of the present. The conference, with its attention to ethnicity, gender, and locality, demonstrated that class itself needed a great deal of rethinking as a working category for understanding working-class social life. Forms of class struggle, said Joseph Ehmer (Max-Planck Institut, Göttingen), citing E. P. Thompson, often exist in societies where class differences do not seem very pronounced: a bread riot, or a Guy Fawkes Day celebration, is both a species of sociability and a form of class struggle.

Helmut Gruber, on behalf of the conference organizers, concluded the meeting by reminding the participants that until a generation ago, the history of the working class had contained no workers at all; only trade union congresses, political parties, and the like. The colloquium had succeeded well in outlining another dimension of the working class, its informal social structures, as a background to the institutional history of the working class. There are different national styles of social history, different approaches to the question of working-class social history, and what was unique about the colloquium was that "we have listened to each other." 